\title{
Public Knowledge, Attitude, and Practice toward COVID-19 Prevention: a Literature Review
}

\author{
Estriana Murni Setiawati*1 \\ ${ }^{1}$ Faculty of Health Sciences, Universitas Aisyiyah Yogyakarta, West Ringroad 63 Street Nogotirto, Gamping, \\ Sleman 55292, Yogyakarta, Indonesia \\ 1estriana.ms@unisayogya.ac.id* \\ *corresponding author \\ Submission date: 21 November 2020, Receipt date: 18 Desember 2020, Publication date: 1 April 2021
}

\begin{abstract}
This study aims to review the public knowledge, attitude, and practice toward COVID-19 prevention. Pubmed, Ebscho, and Google Scholar database were used as Data sources of this review. PICOST problem analysis guide was applied to find good journals. The journals used in this study were published between 2020 and 2021. Overall of the public knowledge, attitude, and practice toward COVID-19 prevention were varied and synthesized. Articles' comparisons were complicated because the knowledge, attitude, and practice results were used at various formulas. A more direct intervention is needed to enhance public knowledge, attitude, and practice toward COVID-19 Prevention. Increasing and maintaining good public knowledge, attitude, and practice toward COVID-19 prevention are crucial to cut off the spread of COVID-19.
\end{abstract}

Keywords: Knowledge, Attitude, Practice, and COVID-19 prevention,

\section{INTRODUCTION}

Corona Virus Disease 2019 (COVID-19) has become a global problem. COVID19 is caused by the SARS-CoV-2 virus. Since December 2019, COVID-19 has had devastating effects within a short time (Azlan, Hamzah, Sern, Ayub, \& Mohamad, 2020). The World Health Organization (WHO) informed that more than 10 million people in the world died from the virus (WHO, 2020). It shortly becomes a global health emergency. Worldwide misinformation about the virus and much fragile health system, the escalating problems caused by COVID-19 are inevitable (Lau et al., 2020). COVID-19 first appeared in China and then spread rapidly in America, Europe and Iran (Pal \& Banerjee, 2020). Then, this virus quickly spread all over the world. COVID-19 effects are mild to severe problems and complications in the respiratory system (Akalu, Ayelign, \& Molla, 2020). Furthermore, Akalu et al. (2020) reported that these disorders and complications would cause distress syndrome, septic shock and even death if they are not adequately resolved.

COVID-19 is easily spread between people, especially if an infected person is in close contact with others. The mouth and nose are good media for transmission of this virus. When infected person cough, sneeze, speak, sing or even breathe heavily, tiny liquid particles could quickly spread to other people through the nose and mouth. This condition more likely to happen when the people in close contact within 1 meter apart. 
These liquid particles have different sizes, from larger respiratory droplets to smaller aerosols (WHO, 2020).

It is crucial to prevent the transmission of COVID-19 to avoid the spreading of COVID-19 (Akalu et al., 2020). The prevention can be done with various methods, such as maintaining distance or physical distancing, wearing masks and washing hands with soap and running water (Akalu et al., 2020). However, the virus transmission still occurs with the case increasing occur every day. Poor understanding of the disease has an impact on improving the spread of the virus. Therefore, transmission prevention management is needed.

Awareness to prevent the transmission of COVID-19 is required to minimize the mortality rate in COVID-19 patients. The new habit of maintaining hand hygiene, wearing masks, and maintaining physical distancing plays an important role. However, this new habit could be performed only with the knowledge and perceptions of the patient. Knowledge, Attitude, and Practice (KAP) is an essential public health cognitive key regarding health prevention and promotion. It covers the cause of the disease and exacerbating factors, identification of symptoms, treatments methods and consequences (Ferdous et al., 2020). Nevertheless, to date, public knowledge, attitude, and practice toward COVID-19 prevention gap of results is inconsistent. Moreover, this review of the literature aimed to assess public knowledge, attitude, and practice toward COVID-19 prevention.

\section{RESEARCH METHODS}

PICOST (Population, Intervention, Comparation, Output, Study, Time) was applied to collect articles in this literature review strategy. It is detailed below,

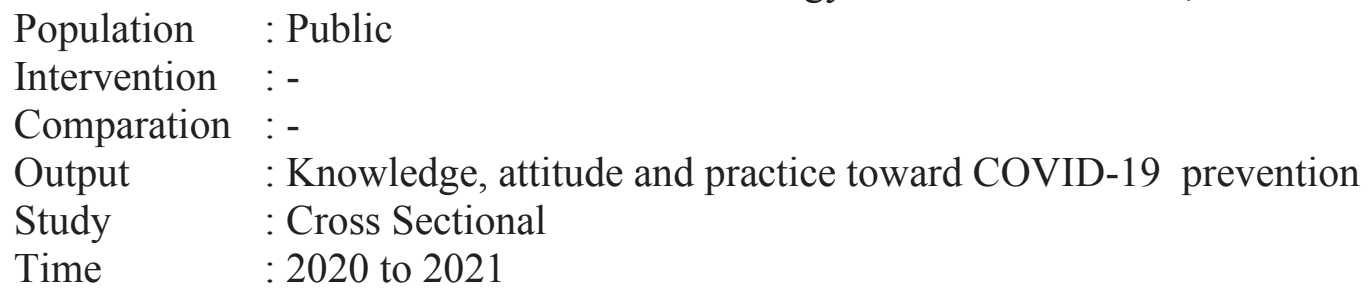

Keywords used for finding the articles were "Public, Knowledge, Attitude, Practice, and COVID-19 prevention". The database used to search for relevant scientific journals was using the Pubmed, Ebscho, and Google Schoolar databases. The literature criteria consist of inclusion and exclusion criteria. The inclusion Criteria in this study were: journals published from the Pubmed, Ebscho, and Google Schoolar databases, the subjects of this study were the public, journal in English language, cross sectional study, vulnerable research time from 2020 to 2021. While the exclusion Criteria in this study were: the journals do not match the research topic, the journal is not in full text, and the journal cannot be accessed.

The quality or feasibility assessment of the Literature Review uses the JBI Critical Appraisals with a minimum standard value for journals can be used for Literature Review is $50 \%$. Literature quality assessment Review using the technical appraisal tool of Cross Sectional form. The literature data collection process was use PRISMA diagram (see Figure 1) 


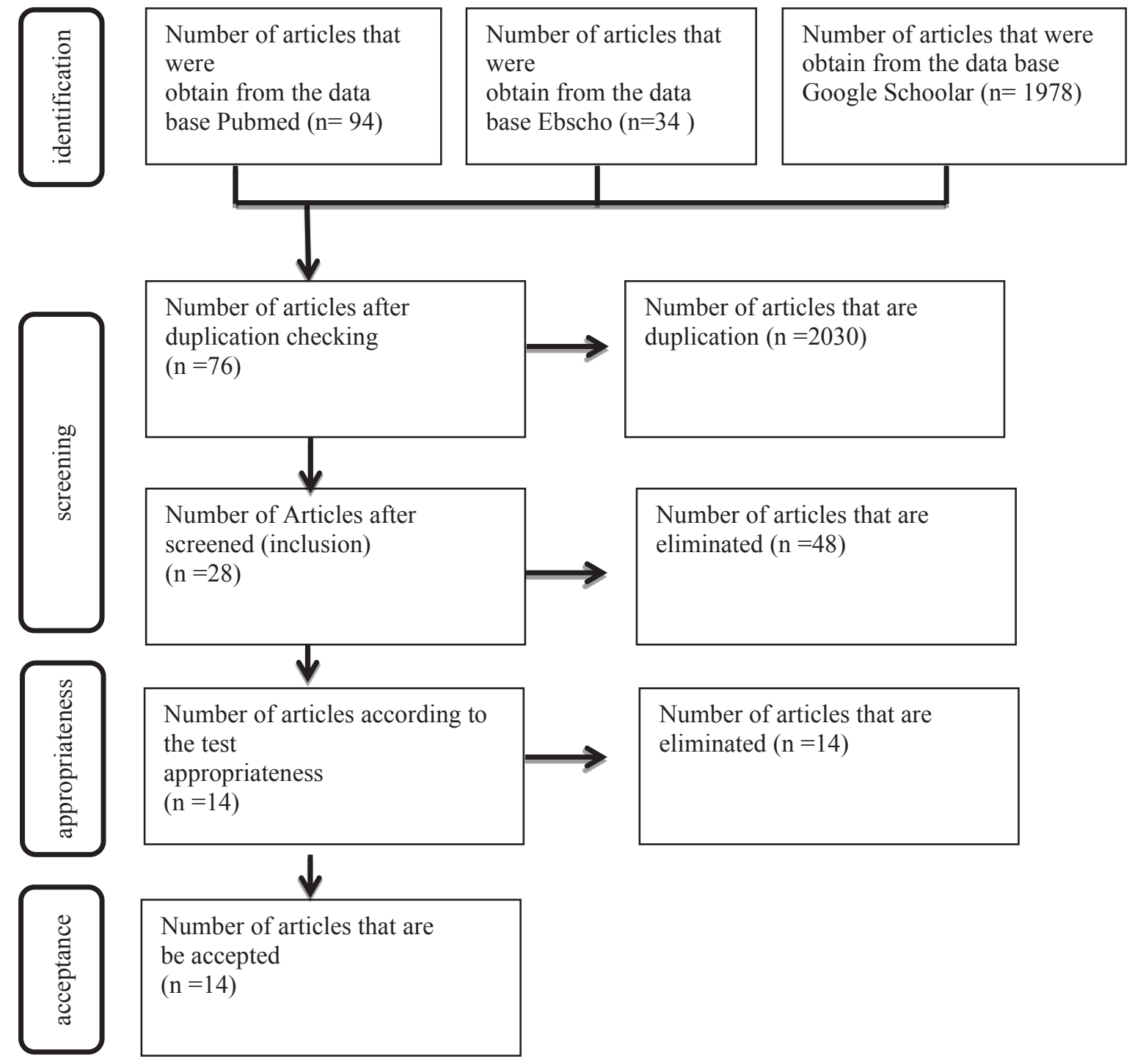

Figure 1. PRISMA diagram for literature review

\section{RESULTS AND DISCUSSION}

\section{Results}

This review used 14 studies that meets the inclusion criteria. Those were published between 2020 and 2021. The most of studies was conducted in Ethiopia and each one study was conducted in China, Bangladesh, Sudan, Congo, Nigeria, Malaysia, India, Uganda, Korea, Syria, Ecuador, Philippines and Malaysia. The sample sizes ranged widely in 330-4850 participants. All of the studies were cross-sectional study with variety of different sampling techniques including convenience sampling (2 studies), purposive sampling (7 studies), snowball (2 studies), simple random sampling (1 study), and multi stage sampling (1 study). Data collection tool was applied by online ( 8 studies), face to face offline interview (4 studies), and both (1 study). 


\section{Knowledge, Attitude, and Practice toward COVID-19 prevention}

Fourteen studies were used to evaluate public knowledge, attitude, and practice regarding COVID-19 (See Table 1). Because of the tool used on the study using various instruments, the findings include overall knowledge, attitude, and practice and different items of knowledge, attitude, and practice questions. Result obtained from many researches showed that knowledge was on low to moderate level as well as attitude and practice.

Table 1. Public Knowledge, Attitude, and Practice toward COVID-19 Prevention

\begin{tabular}{|c|c|c|c|c|}
\hline No & $\begin{array}{l}\text { Author } \\
\text { (Year) } \\
\text { Country, } \\
\text { Design }\end{array}$ & $\begin{array}{l}\text { Instruments } \\
\text { (including the } \\
\text { construct, validity } \\
\text { and reliability), }\end{array}$ & $\begin{array}{l}\text { Data collection } \\
\text { tools, and data } \\
\text { analysis } \\
\text { techniques }\end{array}$ & Results \\
\hline 1 & $\begin{array}{l}\text { Kartheek, } \\
\text { Gara, and } \\
\text { Vanamali } \\
\text { (2020), India, } \\
\text { Cross- } \\
\text { sectional, on } \\
751 \text { Indian } \\
\text { citizens using } \\
\text { Snowball } \\
\text { sampling } \\
\text { technique }\end{array}$ & $\begin{array}{l}\text { The KAP consisted } \\
\text { of questions on the } \\
\text { knowledge, attitude } \\
\text { and practice of } \\
\text { prevention of } \\
\text { COVID-19 which } \\
\text { embraced (a) Clinical } \\
\text { presentation ( } 2 \\
\text { items); (b) } \\
\text { Transmission of } \\
\text { COVID-19 ( } 2 \\
\text { items); (c) Treatment } \\
\text { (3 items); (d) } \\
\text { Preventive measures } \\
\text { (3 items); (e) } \\
\text { Attitudes (4 items) } \\
\text { and (f) Practices (4 } \\
\text { items). Some } \\
\text { knowledge questions } \\
\text { had multiple response } \\
\text { questions with } 1 \text { mark } \\
\text { allotted to each } \\
\text { correct response. The } \\
\text { total COVID-19 } \\
\text { knowledge score } \\
\text { ranged from } 0-22 \text {, a } \\
\text { higher score } \\
\text { indicating better } \\
\text { knowledge }\end{array}$ & $\begin{array}{l}\text { Using Google } \\
\text { forms, and online } \\
\text { semi-structured } \\
\text { questionnaire. } \\
\text { The survey link } \\
\text { was sent through } \\
\text { online platforms } \\
\text { like WhatsApp, e- } \\
\text { mails and } \\
\text { Facebook. }\end{array}$ & $\begin{array}{l}\text { The mean COVID knowledge } \\
\text { score was } 16.28(74 \%) \text {, the } \\
\text { highest score being } 22(100 \%) \text {. } \\
46 \% \text { of participants had a score } \\
\text { of } 80 \% \text { or above. } \\
\text { The accuracy rate for responses } \\
\text { was } 74 \% .87 .2 \%, 84.42 \% \text { and } \\
90.5 \% \text { of participants agreed for } \\
\text { adequate control, won against } \\
\text { COVID-19, and lockdown was } \\
\text { an effective containment } \\
\text { method. Though } 97.6 \% \text { of } \\
\text { respondents agreed about } \\
\text { frequent hand washing, only } \\
77.87 \% \text { confirmed washing } \\
\text { hands } \geq 20 \text { secs. The adherence } \\
\text { to social distancing and } \\
\text { lockdown restrictions was } \\
\text { approved by } 97.3 \% \text { and } 97.3 \% \text {, } \\
\text { respectively. } 13.18 \% \text { of } \\
\text { respondents agreed for a } \\
\text { Hydroxychloroquine purchase. }\end{array}$ \\
\hline 2 & $\begin{array}{l}\text { Gebretsadik } \\
\text { et al. ( } 2021) \text {, } \\
\text { Ethiopia, } \\
\text { Cross- } \\
\text { sectional on } \\
513 \text { hospital } \\
\text { visitors at }\end{array}$ & $\begin{array}{l}\text { There were } 11 \\
\text { questions assessing } \\
\text { knowledge with a } \\
\text { true/false basis } \\
\text { answer. } 1 \text { point for } \\
\text { correct answer and for } \\
\text { an incorrect answer } \\
\text { was assigned } 0 \text { point. }\end{array}$ & $\begin{array}{l}\text { Data collection } \\
\text { was completed } \\
\text { after respondent } \\
\text { filling out the } \\
\text { questionnaire } \\
\text { The descriptive } \\
\text { data such as }\end{array}$ & $\begin{array}{l}56.1 \% \text { of participants answered } \\
\text { that fever, cough, shortness of } \\
\text { breath, sore throat and muscle } \\
\text { pain are not the main clinical } \\
\text { symptoms of COVID- } 19 . \\
212(41.3 \%) \text { responded that } \\
\text { COVID-19 viral infection could }\end{array}$ \\
\hline
\end{tabular}




\begin{tabular}{|c|c|c|c|c|}
\hline No & $\begin{array}{l}\text { Author } \\
\text { (Year) } \\
\text { Country, } \\
\text { Design }\end{array}$ & $\begin{array}{l}\text { Instruments } \\
\text { (including the } \\
\text { construct, validity } \\
\text { and reliability), }\end{array}$ & $\begin{array}{l}\text { Data collection } \\
\text { tools, and data } \\
\text { analysis } \\
\text { techniques }\end{array}$ & Results \\
\hline & $\begin{array}{l}\text { Ataye district } \\
\text { hospital using } \\
\text { Simple } \\
\text { random } \\
\text { sampling } \\
\text { technique }\end{array}$ & $\begin{array}{l}\text { The knowledge of the } \\
\text { participants was } \\
\text { categorized, if the } \\
\text { score was between } 80 \\
\text { and } 100 \% \text { ( } 8.8-11 \\
\text { points) as good, if the } \\
\text { score was between } 60 \\
\text { and } 79 \% \text { (6.6-8.69 } \\
\text { points) as moderate, } \\
\text { and if the score was } \\
\text { less than } 60 \% \text { ( }<6.6 \\
\text { points) as poor. } \\
\text { The questioner } \\
\text { assessing attitude of } \\
\text { the participants } \\
\text { towards COVID-19 } \\
\text { prevention consisted } \\
\text { of } 9 \text { questions. While, } \\
\text { questions assessing } \\
\text { practice composed by } \\
9 \text { questions }\end{array}$ & $\begin{array}{l}\text { frequencies and } \\
\text { percentages were } \\
\text { calculated for } \\
\text { categorical } \\
\text { variables and } \\
\text { mean with } \\
\text { standard } \\
\text { deviations for } \\
\text { continuous } \\
\text { variable }\end{array}$ & 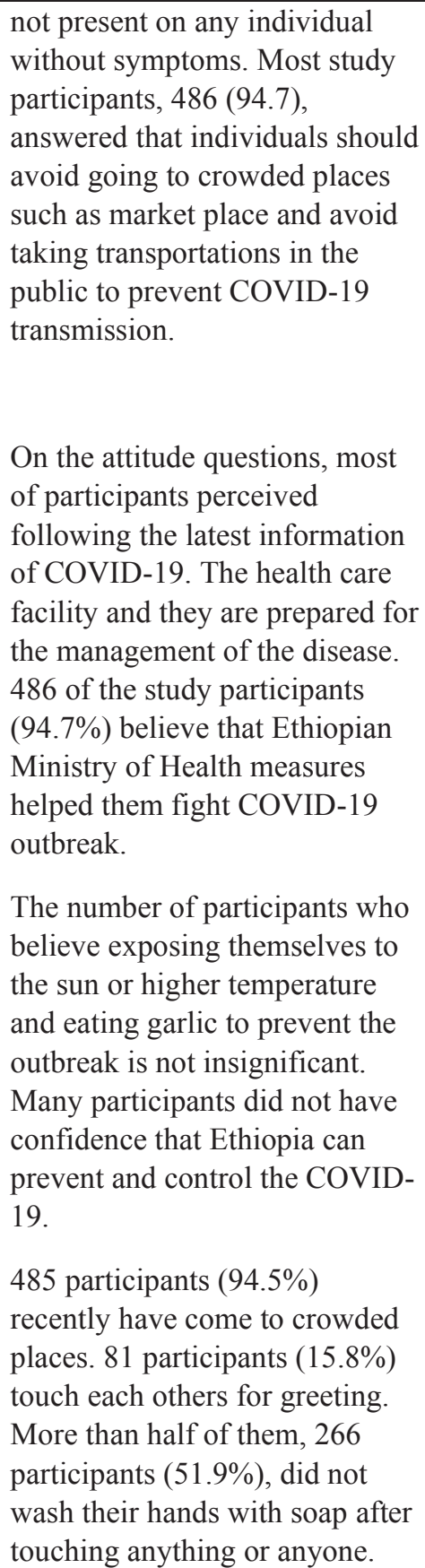 \\
\hline 3 & $\begin{array}{l}\text { Yoseph, } \\
\text { Tamiso, and } \\
\text { Ejeso (2021), } \\
\text { Ethiopia, } \\
\text { Cross- } \\
\text { sectional on } \\
1,278 \text { adult }\end{array}$ & $\begin{array}{l}\text { Using questionnaire } \\
\text { in Sidama language } \\
\text { that was prior tested } \\
\text { on } 5 \% \text { of an overall } \\
\text { calculated sample size } \\
\text { among adult } \\
\text { population in Kebele. }\end{array}$ & $\begin{array}{l}\text { Data collection } \\
\text { was done by } \\
\text { respondents filled } \\
\text { out a } \\
\text { questionnaire } \\
\text { distributed by the } \\
\text { researcher. }\end{array}$ & $\begin{array}{l}\text { The majority of the adult } \\
\text { population } 533(43.9 \%) \text { had } \\
\text { good knowledge about COVID- } \\
19,508(47.8 \%) \text { of the study } \\
\text { respondents had a low attitude } \\
\text { towards the disease, and } 542 \\
(44.6 \%) \text { of respondents had }\end{array}$ \\
\hline
\end{tabular}




\begin{tabular}{|c|c|c|c|c|}
\hline No & $\begin{array}{l}\text { Author } \\
\text { (Year) } \\
\text { Country, } \\
\text { Design }\end{array}$ & $\begin{array}{l}\text { Instruments } \\
\text { (including the } \\
\text { construct, validity } \\
\text { and reliability), }\end{array}$ & $\begin{array}{l}\text { Data collection } \\
\text { tools, and data } \\
\text { analysis } \\
\text { techniques }\end{array}$ & Results \\
\hline & $\begin{array}{l}\text { participants in } \\
\text { Sidama using } \\
\text { Multi-stage } \\
\text { sampling } \\
\text { technique }\end{array}$ & $\begin{array}{l}12 \text { questions } \\
\text { assessing the } \\
\text { knowledge of } \\
\text { COVID-19, } 19 \\
\text { questions were tested } \\
\text { to assess the attitude } \\
\text { towards the COVID- } \\
19 \text { prevention, and } 11 \\
\text { questions was assess } \\
\text { about the practice of } \\
\text { COVID-19 } \\
\text { prevention. }\end{array}$ & $\begin{array}{l}\text { The descriptive } \\
\text { analyses were } \\
\text { done to find out } \\
\text { descriptive } \\
\text { measures for } \\
\text { knowledge, } \\
\text { attitude, and } \\
\text { practice. }\end{array}$ & $\begin{array}{l}\text { weak practice towards COVID- } \\
19 \text { prevention. }\end{array}$ \\
\hline 4 & $\begin{array}{l}\text { Ferdous et al. } \\
(2020) \text {, } \\
\text { Bangladesh, } \\
\text { Cross- } \\
\text { sectional on } \\
2,017 \\
\text { participants } \\
\text { aged 12-64 } \\
\text { years old } \\
\text { using } \\
\text { Purposive } \\
\text { sampling }\end{array}$ & $\begin{array}{l}19 \text { questions with } 6 \text { of } \\
\text { knowledge, } 6 \text { of } \\
\text { attitude, and } 7 \text { of } \\
\text { practice were used to } \\
\text { assess the level of } \\
\text { knowledge, attitude, } \\
\text { and practice of the } \\
\text { participants. } \\
\text { The questionnaire } \\
\text { was validated by } \\
\text { expert validation and } \\
\text { reliability was tested } \\
\text { by } 30 \text { respondents } \\
\text { with Cron- bach's } \\
\text { alpha of KAP was } \\
0.73 \text {. }\end{array}$ & $\begin{array}{l}\text { Online } \\
\text { population-based } \\
\text { survey was used } \\
\text { to assess KAP } \\
\text { (Google Forms). } \\
\text { The link was } \\
\text { shared to public } \\
\text { via social media } \\
\text { (Facebook and } \\
\text { Whats App). } \\
\text { The descriptive } \\
\text { statistics } \\
\text { (frequencies, } \\
\text { percentages, } \\
\text { means, standard } \\
\text { deviations) was } \\
\text { used for measure } \\
\text { KAP }\end{array}$ & $\begin{array}{l}\text { In regards of knowledge, } 48.3 \% \\
\text { of participants had more } \\
\text { accurate knowledge, and } 51.7 \% \\
\text { of respondents had } \\
\text { comparatively inaccurate } \\
\text { knowledge regarding COVID- } \\
19 \text {. } \\
\text { The results indicated that } 62.3 \% \\
\text { of respondents had more } \\
\text { positive attitudes towards } \\
\text { COVID-19. In addition, } 55.2 \% \\
\text { of respondents had more } \\
\text { frequent practices on the } \\
\text { COVID-19 prevention. }\end{array}$ \\
\hline 5 & $\begin{array}{l}\text { Gao et al. } \\
(2020) \text {, } \\
\text { China, Cross- } \\
\text { sectional. } \\
\text { The Kendall } \\
\text { sample } \\
\text { estimation } \\
\text { method was } \\
\text { used to } \\
\text { calculate the } \\
\text { sample. The } \\
\text { minimum } \\
\text { sample size } \\
\text { of } \\
\text { participants } \\
\text { were required }\end{array}$ & $\begin{array}{l}\text { The Knowledge } \\
\text { section consists of } 13 \\
\text { questions, the attitude } \\
\text { section there was } 5 \\
\text { questions, and } \\
\text { practice section } \\
\text { consisted of } 15 \\
\text { questions. The CVI of } \\
\text { the questionnaire was } \\
\text { found } 0.94 \text {, and the } \\
\text { Cronbach's } \alpha \text { value } \\
\text { was } 0.846 \text {. }\end{array}$ & $\begin{array}{l}\text { Conducted by } \\
\text { online survey on a } \\
\text { special } \\
\text { questionnaire } \\
\text { survey platform } \\
\text { (Wen- juanxing) } \\
\text { and the link } \\
\text { shared by } \\
\text { WeChat. } \\
\text { Frequencies and } \\
\text { composition ratios } \\
\text { were used to } \\
\text { describe the } \\
\text { categorical data. }\end{array}$ & $\begin{array}{l}\text { The accurate response rate for } \\
\text { the knowledge section ranged } \\
\text { from } 72.7 \% \text { to } 99.5 \% \text {. } \\
\text { The proportion of positive } \\
\text { attitudes ranged from } 94.7 \% \text { to } \\
99.7 \% \text {. } \\
\text { The proportion of good practices } \\
\text { ranged from } 76.1 \% \text { to } 99.5 \% \text {. }\end{array}$ \\
\hline
\end{tabular}




\begin{tabular}{|c|c|c|c|c|}
\hline No & $\begin{array}{l}\text { Author } \\
\text { (Year) } \\
\text { Country, } \\
\text { Design }\end{array}$ & $\begin{array}{l}\text { Instruments } \\
\text { (including the } \\
\text { construct, validity } \\
\text { and reliability), }\end{array}$ & $\begin{array}{l}\text { Data collection } \\
\text { tools, and data } \\
\text { analysis } \\
\text { techniques }\end{array}$ & Results \\
\hline & $\begin{array}{l}\text { to be } 10 \text { times } \\
\text { the number of } \\
\text { variables that } \\
\text { was } 330 \\
\text { participants, } \\
\text { Convenience } \\
\text { sampling }\end{array}$ & & $\begin{array}{l}\text { The continuous } \\
\text { data were } \\
\text { described as the } \\
\text { means and } \\
\text { standard } \\
\text { deviations. }\end{array}$ & \\
\hline 6 & $\begin{array}{l}\text { Okello, Izudi, } \\
\text { Teguzirigwa, } \\
\text { Kakinda, and } \\
\text { Van Hal } \\
\text { (2020), } \\
\text { Uganda, } \\
\text { Cross- } \\
\text { sectional, } \\
\text { Sample size } \\
\text { calculated by } \\
\text { Yamane's } \\
\text { formula. } 362 \\
\text { participants } \\
\text { accepted to } \\
\text { join to the } \\
\text { research, } \\
\text { Purposive } \\
\text { sampling }\end{array}$ & $\begin{array}{l}\text { The questionnaire had } \\
\text { questions about KAP. } \\
\text { It was developed } \\
\text { using the Uganda } \\
\text { MoH and the World } \\
\text { Health Organization } \\
\text { (WHO) guidelines on } \\
\text { COVID- } 19 \\
\text { prevention. } \\
\text { The Knowledge } \\
\text { section consists of } 16 \\
\text { questions, the attitude } \\
\text { section there was } 5 \\
\text { questions, and } \\
\text { practice section } \\
\text { consisted of } 10 \\
\text { questions. } \\
\text { Pilot study was } \\
\text { conducted an online } \\
\text { in the neighboring } \\
\text { country, Kenya. }\end{array}$ & $\begin{array}{l}\text { Conducted by } \\
\text { online } \\
\text { (KoboToolbox) } \\
\text { and share the link } \\
\text { via WhatsApp, } \\
\text { Facebook, } \\
\text { Twitter, and } \\
\text { instagram. } \\
\\
\text { The descriptive } \\
\text { statistic on } \\
\text { categorical data } \\
\text { using frequencies } \\
\text { and percentages } \\
\text { and numerical } \\
\text { data using means } \\
\text { with standard } \\
\text { deviations or } \\
\text { medians with } \\
\text { interquartile } \\
\text { ranges (IQR). }\end{array}$ & $\begin{array}{l}\text { No differences in the proportion } \\
\text { of knowledge about COVID-19 } \\
\text { with consideration to } \\
\text { sociodemographic } \\
\text { characteristics data. } \\
\text { It is observed statistically } \\
\text { significant differences in the } \\
\text { proportion of positive attitudes } \\
\text { on presidential directives and } \\
\text { MoH guidelines on behalf of } \\
\text { education level (p = 0:019). } \\
\text { In spite of the high level of } \\
\text { knowledge about COVID-19 } \\
\text { among the respondents, overall, } \\
\text { less than half of the respondents } \\
\text { (48.3\%) were adherent to } \\
\text { practising the COVID-19 } \\
\text { prevention of transmission. }\end{array}$ \\
\hline 7 & $\begin{array}{l}\text { Lee, Kang, } \\
\text { and You } \\
(2021) \text {, } \\
\text { Korea, Cross- } \\
\text { sectional on } \\
970 \\
\text { participants } \\
\text { using } \\
\text { Purposive } \\
\text { sampling }\end{array}$ & $\begin{array}{l}\text { The knowledge was } \\
\text { assessed by } 6 \\
\text { questions, while } \\
\text { attitude and practice } \\
\text { were assessed by } 2 \\
\text { and } 3 \text { questions. }\end{array}$ & $\begin{array}{l}\text { Descriptive } \\
\text { statistic was } \\
\text { reported by mean } \\
(\mathrm{M}), \text { standard } \\
\text { deviation (SD), } \\
\text { and frequency } \\
\text { (percent- age \%). }\end{array}$ & $\begin{array}{l}\text { Most participants answered } \\
\text { about four of six knowledge } \\
\text { items correctly }(\mathrm{M}=4.21, \mathrm{SD}= \\
1.16) \text {. } \\
\text { Participants perceived the risk of } \\
\text { becoming infected with COVID- } \\
19 \text { (perceived susceptibility) as } \\
\text { lower than "neither high nor } \\
\text { low" (score = 3) (M=2.77, SD } \\
=0.80) \text {; the average perceived } \\
\text { severity score was higher than } \\
\text { perceived susceptibility, which } \\
\text { was close to "high" (score }=4) \\
\text { (M=3.77, SD = } 0.85) \text {. Both } \\
\text { efficacy beliefs on preventive } \\
\text { measures (M = 3.82, SD = } 0.44 \text { ) }\end{array}$ \\
\hline
\end{tabular}




\begin{tabular}{|c|c|c|c|c|}
\hline No & $\begin{array}{l}\text { Author } \\
\text { (Year) } \\
\text { Country, } \\
\text { Design }\end{array}$ & $\begin{array}{l}\text { Instruments } \\
\text { (including the } \\
\text { construct, validity } \\
\text { and reliability), }\end{array}$ & $\begin{array}{l}\text { Data collection } \\
\text { tools, and data } \\
\text { analysis } \\
\text { techniques }\end{array}$ & Results \\
\hline & & & & $\begin{array}{l}\text { and social distancing }(\mathrm{M}=3.66 \text {, } \\
\mathrm{SD}=0.59) \text { were high. } \\
\text { The most often performed } \\
\text { practice was wearing facial } \\
\text { masks }(\mathrm{M}=3.82, \mathrm{SD}=0.49), \\
\text { followed by practicing hand } \\
\text { hygiene }(\mathrm{M}=3.51, \mathrm{SD}=0.66) \\
\text { and social distancing }(\mathrm{M}=3.11 \text {, } \\
\mathrm{SD}=0.90)\end{array}$ \\
\hline 8 & $\begin{array}{l}\text { Azlan et al. } \\
(2020), \\
\text { Malaysia, } \\
\text { Cross- } \\
\text { sectional on } \\
4,850 \\
\text { respondents } \\
\text { using } \\
\text { Purposive } \\
\text { sampling }\end{array}$ & $\begin{array}{l}\text { The knowledge } \\
\text { section was assessed } \\
\text { by } 13 \text { questions, } \\
\text { whereas, attitude } \\
\text { section as assessed by } \\
3 \text { questions as well as } \\
\text { practice section. } \\
\text { The Cronbach alpha } \\
\text { for knowledge section } \\
\text { was } 0.655 \text {. }\end{array}$ & $\begin{array}{l}\text { Online employ } \\
\text { the Survey } \\
\text { Monkey plat- } \\
\text { form. The link } \\
\text { was share by } \\
\text { social media. } \\
\\
\text { Descriptive } \\
\text { analysis was } \\
\text { measured by } \\
\text { frequencies, and } \\
\text { percentages. }\end{array}$ & $\begin{array}{l}\text { The average knowledge score } \\
\text { for respondents were } 10.5 \text { (SD = } \\
\text { 1.4, range } 0-13) \text {. } \\
\text { The overall correct rate of the } \\
\text { knowledge section was } 80.5 \% \text {. } \\
\text { Most respondents held positive } \\
\text { attitudes toward the successful } \\
\text { control of COVID-19 ( } 83.1 \%) \text {. } \\
\text { Most respondents were also } \\
\text { taking precautions such as } \\
\text { avoiding crowds ( } 83.4 \%) \text { and } \\
\text { practicing proper hand hygiene } \\
\text { (87.8\%) in the week before the } \\
\text { movement control order started. } \\
\text { The face masks wearing was less } \\
\text { common }(51.2 \%) \text {. }\end{array}$ \\
\hline 9 & $\begin{array}{l}\text { Lau et al. } \\
(2020), \\
\text { Philippines, } \\
\text { Cross- } \\
\text { sectional on } \\
2224 \\
\text { respondents } \\
\text { using } \\
\text { Purposive } \\
\text { sampling }\end{array}$ & $\begin{array}{l}\text { The KAP } \\
\text { questionnaire consist } \\
\text { of } 16 \text { questions }\end{array}$ & $\begin{array}{l}\text { Conducted by } \\
\text { face to face } \\
\text { interviews and all } \\
\text { survey data were } \\
\text { collected on } \\
\text { mobile devices } \\
\text { using } \\
\text { SurveyCTO, a } \\
\text { computer-aided } \\
\text { personal } \\
\text { interviewing } \\
\text { (CAPI) platform } \\
\text { which collects } \\
\text { responses via an } \\
\text { app and stores } \\
\text { data in a secure } \\
\text { server. }\end{array}$ & $\begin{array}{l}94.0 \% \text { of participants had } \\
\text { already heard of COVID- } 19 . \\
\text { Coughing and sneezing were } \\
\text { known as a transmission route } \\
\text { by } 89.5 \% \text { of participants, while } \\
\text { indirect hand contact was the } \\
\text { least commonly identified } \\
\text { spread route, recognized by } \\
72.6 \% \text { of participants . } \\
\text { Handwashing was identified by } \\
82.2 \% \text { of participants as a } \\
\text { preventive measure against the } \\
\text { virus, but social distancing and } \\
\text { avoiding crowds were only } \\
\text { identified by } 32.4 \% \text { and } 40.6 \% \text {, } \\
\text { respectively. Hand washing was } \\
\text { the most common practice in } \\
\text { response to COVID-19 } \\
\text { prevention, applied by } 89.9 \% \text { of } \\
\text { participants }\end{array}$ \\
\hline
\end{tabular}




\begin{tabular}{|c|c|c|c|c|}
\hline No & $\begin{array}{l}\text { Author } \\
\text { (Year) } \\
\text { Country, } \\
\text { Design }\end{array}$ & $\begin{array}{l}\text { Instruments } \\
\text { (including the } \\
\text { construct, validity } \\
\text { and reliability), }\end{array}$ & $\begin{array}{l}\text { Data collection } \\
\text { tools, and data } \\
\text { analysis } \\
\text { techniques }\end{array}$ & Results \\
\hline & & & $\begin{array}{l}\text { Frequencies and } \\
\text { proportions were } \\
\text { used to describe } \\
\text { the participants' } \\
\text { knowledge, } \\
\text { attitude and } \\
\text { practice toward } \\
\text { COVID-19 } \\
\text { prevention. }\end{array}$ & \\
\hline 10 & $\begin{array}{l}\text { Ahdab } \\
\text { (2021), Syria, } \\
\text { Cross- } \\
\text { sectional on } \\
706 \\
\text { respondents } \\
\text { using } \\
\text { Purposive } \\
\text { sampling }\end{array}$ & $\begin{array}{l}\text { KAP questionnaire } \\
\text { consist of } 6 \text { questions } \\
\text { on knowledge section, } \\
4 \text { and } 8 \text { questions on } \\
\text { attitude and practice } \\
\text { section, respectively. }\end{array}$ & $\begin{array}{l}\text { a web-based } \\
\text { questionnaire that } \\
\text { was posted on the } \\
\text { social media } \\
\text { (facebook and } \\
\text { whats app). } \\
\text { Descriptive } \\
\text { analysis was } \\
\text { measured by } \\
\text { frequencies, and } \\
\text { percentages. }\end{array}$ & $\begin{array}{l}\text { Overall knowledge score on } \\
\text { COVID- } 19 \text { was about } 60 \% \\
\text { (mean score } 3.54 \pm 1.20 ; \text { range } \\
0-6 \text {. While, attitude and practice } \\
\text { scores were } 2.45 \pm 0.81 \text { (range } \\
0-4 \text { ), } 5.90 \pm 1.52 \text { (range } 0-8 \text { ), } \\
\text { respectively. }\end{array}$ \\
\hline 11 & $\begin{array}{l}\text { Mohamed et } \\
\text { al. (2021), } \\
\text { Sudan, Cross- } \\
\text { sectional, } \\
\text { Sample size } \\
\text { was } \\
\text { calculated by } \\
\text { Open Epi- } \\
\text { calculator. } \\
987 \\
\text { respondents } \\
\text { were } \\
\text { recruited and } \\
\text { completely } \\
\text { fill the } \\
\text { questionnaire. } \\
\\
\text { Snowballing } \\
\text { sampling }\end{array}$ & $\begin{array}{l}18 \text { knowledge } \\
\text { questions, } 5 \text { questions } \\
\text { for attitude and six } \\
\text { questions for } \\
\text { practices were used to } \\
\text { assess KAP. }\end{array}$ & $\begin{array}{l}\text { Research } \\
\text { conducted by } \\
\text { posted the } \\
\text { questionnaire } \\
\text { (Google form) } \\
\text { link on social } \\
\text { media (facebook } \\
\text { and whatsapp). } \\
\\
\text { Descriptive } \\
\text { analysis was } \\
\text { measured by } \\
\text { mean, and } \\
\text { standard } \\
\text { deviation. }\end{array}$ & $\begin{array}{l}\text { The mean }( \pm \mathrm{SD}) \text { knowledge } \\
\text { score of the respondents was } \\
15.33( \pm 2.24) \text { and was found to } \\
\text { be correlated with education } \\
\text { level and age groups (p-value = } \\
0.022, \mathrm{P} \text {-value }=0.010) \text {. The } \\
\text { mean }( \pm \mathrm{SD}) \text { attitude score was } \\
04.15( \pm 0.97) \text { and was } \\
\text { significantly correlate with older } \\
\text { groups and better-educated } \\
\text { respondents (p-value }=0.001, \mathrm{p}- \\
\text { value }=0.048) \text { respectively. The } \\
\text { COVID-19 mean }( \pm \mathrm{SD}) \\
\text { practices were } 02.58( \pm 1.73) \\
\text { with a significant difference } \\
\text { between age groups and area of } \\
\text { residence. }\end{array}$ \\
\hline 12 & $\begin{array}{l}\text { Kuhangana et } \\
\text { al. }(2020) \text {, } \\
\text { Congo, } \\
\text { Cross- } \\
\text { sectional on }\end{array}$ & $\begin{array}{l}10 \text { knowledge } \\
\text { questions, } 10 \\
\text { questions for attitude } \\
\text { and for practices } \\
\text { section measure by }\end{array}$ & $\begin{array}{l}\text { Conducted by } \\
\text { face to face } \\
\text { interviews. } \\
\text { Descriptive } \\
\text { analysis was }\end{array}$ & $\begin{array}{l}\text { Two-thirds of the participants } \\
\text { did not know about COVID-19 } \\
\text { and } 60 \% \text { answered that the } \\
\text { COVID- } 19 \text { pandemic was not } \\
\text { present in the DRC. The }\end{array}$ \\
\hline
\end{tabular}




\begin{tabular}{|c|c|c|c|c|}
\hline No & $\begin{array}{c}\text { Author } \\
\text { (Year) } \\
\text { Country, } \\
\text { Design }\end{array}$ & $\begin{array}{l}\text { Instruments } \\
\text { (including the } \\
\text { construct, validity } \\
\text { and reliability), }\end{array}$ & $\begin{array}{l}\text { Data collection } \\
\text { tools, and data } \\
\text { analysis } \\
\text { techniques }\end{array}$ & Results \\
\hline & $\begin{array}{l}347 \\
\text { respondents } \\
\text { were included } \\
\text { using } \\
\text { Purposive } \\
\text { sampling }\end{array}$ & $\begin{array}{l}\text { researcher } \\
\text { observation }\end{array}$ & $\begin{array}{l}\text { measured by } \\
\text { frequencies, and } \\
\text { percentages. }\end{array}$ & $\begin{array}{l}\text { majority of participants }(65 \%) \\
\text { were unaware of the possible } \\
\text { COVID-19 transmission by } \\
\text { asymptomatic patients. } \\
13 \% \text { of the respondents were } \\
\text { prepared to visit a COVID-19- } \\
\text { infected neighbor or colleague, } \\
\text { and } 31 \% \text { would visit an infected } \\
\text { family member. } 97 \% \\
\text { respondents reported using } \\
\text { public transportation, which in } \\
\text { the area consists of generally } \\
\text { cramped small minivans. } \\
\text { In general, social distancing was } \\
\text { not respected, nowhere } \\
\text { researcher observe either sellers } \\
\text { or buyers washing their hands } \\
\text { after reciprocal contacts. }\end{array}$ \\
\hline 13 & $\begin{array}{l}\text { Habib, } \\
\text { Dayyab, } \\
\text { Iliyasu, and } \\
\text { Habib (2021), } \\
\text { Nigeria, } \\
\text { Cross- } \\
\text { sectional on } \\
886 \\
\text { participants, } \\
\text { using } \\
\text { Convenience } \\
\text { sampling }\end{array}$ & $\begin{array}{l}\text { The percentage of } \\
\text { KAP scores were in } \\
\text { good and poor. } 25 \\
\text { random respondents } \\
\text { was applied to check } \\
\text { Validity and } \\
\text { reliability of the } \\
\text { questionnaire. }\end{array}$ & $\begin{array}{l}\text { Conducted by } \\
\text { face to face } \\
\text { interviews and } \\
\text { online. } \\
\text { Descriptive } \\
\text { analysis was } \\
\text { measured by } \\
\text { mean, standard } \\
\text { deviation and } \\
\text { inter-quartile } \\
\text { ranges. }\end{array}$ & $\begin{array}{l}\text { The overall mean [standard } \\
\text { deviation] (inter-quartile ranges) } \\
\text { for knowledge score was } \\
65.38 \% \text { [SD 15.90] (IQR: } \\
55.36-77.8 \% \text { ), attitude score } \\
\text { was } 71.45 \% \text { [SD 14.10] (IQR: } \\
60.87-82.61 \% \text { ) and practice } \\
\text { scores was } 65.04 \% \text { [SD } 17.02 \text { ] } \\
\text { (IQR: } 57.14-76.19 \%) .270 \\
\text { respondents }(30.47 \% \text { ) had Good } \\
\text { Knowledge, } 158(17.8 \% \text { ) had } \\
\text { Good Attitude and } 230 \text { ( } 25.96 \% \text { ) } \\
\text { had Good Practice using cut-off } \\
\text { scores of } 75 \%, 86.5 \% \text { and } 75 \% \\
\text { respectively }\end{array}$ \\
\hline 14 & $\begin{array}{l}\text { Bates et al. } \\
(2020), \\
\text { Ecuador, } \\
\text { Cross- } \\
\text { sectional on } \\
2399 \\
\text { participants } \\
\text { using } \\
\text { snowball and } \\
\text { referral } \\
\text { sampling }\end{array}$ & $\begin{array}{l}12 \text { knowledge } \\
\text { questions, } 2 \text { questions } \\
\text { for attitude and } 3 \\
\text { questions for } \\
\text { practices were used to } \\
\text { assess KAP. }\end{array}$ & $\begin{array}{l}\text { Conducted by } \\
\text { internet-based } \\
\text { questionnaire } \\
\text { (Qualtrics } \\
\text { platform) via } \\
\text { Facebook. } \\
\text { Descriptive } \\
\text { analysis was } \\
\text { measured by } \\
\text { Frequencies of the } \\
\text { answers }\end{array}$ & $\begin{array}{l}\text { Participants had moderate to } \\
\text { high } \\
\text { levels of knowledge. } \\
\text { Participants expressed mixed } \\
\text { attitudes about the eventual } \\
\text { control of COVID-19 in } \\
\text { Ecuador. Participants } \\
\text { reported high levels of adoption } \\
\text { of preventive practices. }\end{array}$ \\
\hline
\end{tabular}




\begin{tabular}{|c|c|c|c|c|}
\hline No & $\begin{array}{c}\text { Author } \\
\text { (Year) } \\
\text { Country, } \\
\text { Design }\end{array}$ & $\begin{array}{c}\text { Instruments } \\
\text { (including the } \\
\text { construct, validity } \\
\text { and reliability), }\end{array}$ & $\begin{array}{c}\text { Data collection } \\
\text { tools, and data } \\
\text { analysis } \\
\text { techniques }\end{array}$ & Results \\
\hline & & & & \\
\hline
\end{tabular}

\section{Discussion}

The studies' limitations indicate the need for caution in drawing conclusions and synthesizing information about knowledge, attitude and practice toward COVID-19 prevention. Restrictions in the instrument, as well as methodology aspects of the literature, are worth it.

\section{Knowledge toward COVID-19 prevention}

The study conducted in Congo (Kuhangana et al., 2020) and the Philippines (Lau et al., 2020) were found that the level of knowledge was low, and Kartheek et al. (2020) said that the knowledge toward COVID-19 showed by the inadequate result. The possible explanation of the low knowledge of this study might be because of the demographic characteristic like the study by Kuhangana et al. (2020) and Lau et al. (2020) which the traditional media source of information (television and radio) was used. Whereas inadequate knowledge could be due to the myths and misinformation because of fear, blame and stigma recommend that public health practitioners and policymakers promote knowledge and understanding while addressing contextual factors that may hinder the public's learning processes concerning health information to overcome misinformation (Kartheek et al., 2020; Lee et al., 2021). Other reason might be due to the lack access to health care provider and information regarding COVID-19 (Lau et al., 2020).

Moreover, even though they have inadequate knowledge, the proportion of the low level of knowledge were decreased. The reason might be since the current study was conducted after most of the population obtained information about the disease in several ways (Gebretsadik et al., 2021). Gebretsadik et al. (2021) and Yoseph et al. (2021) also stated that it might be due to the study participants getting access to the internet service, which helped them find information about the disease from several sources. Other studies showed that the excellent knowledge of COVID-19 might be due to the study respondents live in urban residence with higher education degree (Gao et al., 2020; Mohamed et al., 2021).

\section{Attitude toward COVID-19 prevention}

Many researchers reported that public attitude toward COVID-19 was optimistic (Azlan et al., 2020; Gao et al., 2020; Kartheek et al., 2020; Okello et al., 2020; Yoseph et al., 2021). This is possible because the belief can pass this situation and win against the disease by supporting lockdown decision and following restrictive policies (Kartheek et al., 2020). Efficacy beliefs had a significant and robust impact on practising preventive behaviours, implying promoting preventive behaviours toward COVID-19 (Ahdab, 2021; Azlan et al., 2020; Lee et al., 2021; Okello et al., 2020). It was also possibly due to the media report on the severity of the disease. It made the respondents desire to participate 
actively prevent and control it (Gao et al., 2020). Other studies showed that it might be because the availability of hand washing facilities (Lau et al., 2020; Mohamed et al., 2021). It was suggested that promoting an improved understanding of COVID-19 may also help enhance confidence that COVID-19 finally be controlled (Bates et al., 2020).

On the contrary, Gebretsadik et al. (2021) revealed that the public attitude toward the disease was pessimistic. It could be due to the majority of the respondents having no internet access or living in the rural area so that they have less information about the disease and have financial barriers that would impact their attitude toward COVID-19 (Ferdous et al., 2020; Lee et al., 2021). Other studies revealed that the attitude to wear mask was low (Ahdab, 2021; Mohamed et al., 2021). The result might be that the mask's price was high, no law enforcement, and inconsistent information about wearing the mask in the public area (Mohamed et al., 2021).

\section{Practice toward COVID-19 prevention}

The practice of prevention of COVID-19 showed by washing hand. However, due to inadequate knowledge, the people did not follow the regulation of washing their hands more than 20 seconds (Kartheek et al., 2020). The result might be because the respondents have insufficient knowledge that would relate to the practice (Lau et al., 2020; Lee et al., 2021; Yoseph et al., 2021). Another study showed that the low hand hygiene practice was due to a lack of handwashing facilities (Kartheek et al., 2020).

On the contrary, Gao et al. (2020) showed that the respondent in China had good practice regarding COVID-19 prevention, similar to the respondent in Uganda (Okello et al., 2020) and Malaysia (Azlan et al., 2020). The reason might be that the respondent has good knowledge and a positive attitude that applied into good practice (Ahdab, 2021; Gao et al., 2020; Lee et al., 2021). This represents a willingness for respondents to make behavioural changes during the COVID-19 pandemic (Azlan et al., 2020). A study conducted in Ecuador revealed that the respondent has a positive attitude by washing hand more than 20 seconds and maintaining physical distancing about 2 meters from others (Bates et al., 2020).

Regarding Muslim religion, obligations and prayers that Muslims attend and would still go ahead and attend burial rites, Eid prayer and Friday prayer, respectively, despite existing lockdown measures (Habib et al., 2021). These findings all support the need for more communication, community engagement, and local leaders to promote adherence to strict social distancing methods. Religious leaders should be enlightened about the scale of the pandemic and its consequences. Knowledge of transmission of the virus should be communicated clearly, and several misconceptions should be clarified, and rumours promptly dispelled (Habib et al., 2021).

The study's limitation was the differences in measurement and scoring systems do not make it possible for accurate comparisons of knowledge, attitude, and practice levels across these studies.

\section{CONCLUSION}

In conclusion, our findings indicate that the respondents were likely to have low to high levels of knowledge, pessimistic to optimistic attitude, and low to good practice related to COVID-19 prevention with different demographic characteristics. Meanwhile, our study findings suggest that formulating appropriate interventions is needed to gain 
public knowledge, attitude, and practice toward COVID-19 Prevention. It is essential to enhance public knowledge, attitude, and practice toward COVID-19 prevention to cut off the spread of COVID-19, particularly among rural, poor, and low education level residents.

\section{REFERENCES}

Ahdab, S. A. (2021). A cross-sectional survey of knowledge, attitude and practice (KAP) towards COVID-19 pandemic among the Syrian residents. BMC Public Health, 21, 1-7. doi:10.1186/s12889-021-10353-3

Akalu, Y., Ayelign, B., \& Molla, M. D. (2020). Knowledge, attitude and practice towards COVID-19 among chronic disease patients at Addis Zemen Hospital, Northwest Ethiopia. Infection and drug resistance, 13, 1949-1960. doi:10.2147/IDR.S258736

Azlan, A., Hamzah, M., Sern, T., Ayub, S., \& Mohamad, E. (2020). Public knowledge, attitudes and practices towards COVID-19: A cross-sectional study in Malaysia. PloS one, 15(5), 1-15. doi:10.1371/journal.pone.0233668

Bates, B. R., Moncayo, A. L., Costales, J. A., Herrera-Cespedes, A, C., \& Grijalva, M. J. (2020). Knowledge, Attitudes, and Practices Towards COVID-19 Among Ecuadorians During the Outbreak: An Online Cross-Sectional Survey. Journal of Community Health 1-10. doi:10.1007/s10900-020-00916-7

Ferdous, M. Z., Islam, M. S., Sikder, M. T., Mosaddek, A. S. M., Zegarra-Valdivia, J. A., \& Goza, D. (2020). Knowledge, attitude, and practice regarding COVID-19 outbreak in Bangladesh: An online-based cross-sectional study. PloS one, 15(1), 1-17. doi:10.1371/journal.pone.0239254

Gao, H., Hu, R., Yin, L., Yuan, X., Tang, H., Luo, L., .. . Jiang, Z. (2020). Knowledge, Attitudes and Practices of the Chinese Public with Respect to Coronavirus Disease (COVID-19): an online Cross Sectional Survey. BMC Public Health, 20, 1-8. doi:10.1186/s12889-020-09961-2

Gebretsadik, D., Ahmed, N., KebedeI, E., GebremichealI, S., BeleteI, M., \& Adane, M. (2021). Knowledge, Attitude, Practice towards COVID-19 Pandemic and Its Prevalence among Hospital Visitors at Ataye District Hospital, Northeast Ethiopia. PloS one, 16(2), 1-19. doi:10.1371/journal.pone.0246154

Habib, M. A., Dayyab, F. M., Iliyasu, G., \& Habib, A. G. (2021). Knowledge, attitude and practice survey of COVID-19 pandemic in Northern Nigeria. PloS one, 16(1), 1-12. doi:10.1371/journal.pone. 0245176

Kartheek, A., Gara, K., \& Vanamali, D. (2020). Knowledge, Attitude and Practices towards COVID-19 among Indian Residents during The Pandemic: A Cross-Sectional Online Survey. Journal of Dr. NTR University of Health Sciences, 9(2), 107-115. doi:10.4103/JDRNTRUHS.JDRNTRUHS_75_2

Kuhangana, T. C., Mbayo, C. K., Kitenge, J. P., Ngoy, A. K., Musambo, T. M., Obadia, P. M., ... Nemery, B. (2020). COVID-19 Pandemic: Knowledge and Attitudes in Public Markets in the Former Katanga Province of the Democratic Republic of 
Congo. International Journal of Environmental Research and Public Health, 17, 1-16. doi:10.3390/ijerph17207441

Lau, L., Hung, N., Go, D., Ferma, J., Choi, M., Dodd, W., \& Wei, X. (2020). Knowledge, attitudes and practices of COVID-19 among income-poor households in the Philippines: A cross-sectional study. Journal of Global Health, 10(1), 1-11. doi:10.7189/jogh.10.011007

Lee, M., Kang, B.-A., \& You, M. (2021). Knowledge, attitudes, and practices (KAP) toward COVID-19: a cross-sectional study in South Korea. BMC Public Health, 21, 1-10. doi:10.1186/s12889-021-10285-y

Mohamed, A. A. O., Elhassan, E. A. M., Mohamed, A. O., Mohammed, A. A., Edris, H. A., Mahgoop, M. A., . . Malik, E. M. (2021). Knowledge, attitude and practice of the Sudanese people towards COVID-19: an online survey. BMC Public Health, 21, 1-7. doi:10.1186/s12889-021-10319-5

Okello, G., Izudi, J., Teguzirigwa, S., Kakinda, A., \& Van Hal, G. (2020). Findings of a Cross-Sectional Survey on Knowledge, Attitudes, and Practices about COVID19 in Uganda: Implications for Public Health Prevention and Control Measures. BioMed Research International, 1-8. doi:10.1155/2020/5917378

Pal, R., \& Banerjee, M. (2020). COVID-19 and the endocrine system: exploring the unexplored. Journal of endocrinological investigation, 43(7), 1027-1031. doi:10.1007/s40618-020-01276-8

WHO. (2020). Coronavirus disease (COVID-19): How is it transmitted? Retrieved from https://www.who.int/news-room/q-a-detail/coronavirus-disease-covid-19-howis-it-transmitted

Yoseph, A., Tamiso, A., \& Ejeso, A. (2021). Knowledge, Attitudes, and Practices related to COVID-19 Pandemic among Adult Population in Sidama Regional State, Southern Ethiopia: A Community based Cross-Sectional Study. PloS one, 16(1), 1-19. doi:10.1371/journal.pone.0246283 